\title{
From locked cupboard to university library : libraries for nurses in the UK after 1955
}

\author{
Maurice Wakeham
}

\author{
Academic Liaison Librarian : Health and Social Care \\ Anglia Polytechnic University
}

\begin{abstract}
This paper presents an outline of the history of library provision for nurses in the second half of the twentieth century. The few libraries for nurses that existed in the fifties were usually attached to Schools of Nursing and often run by volunteers, clerical assistants or nurse tutors. In an organisation where the emphasis was on training and skills development rather than education and reflection and the prime aim was maintaining a health service with limited resources, provision of books and journals for theoretical learning had a low priority. In turn nurses gained a reputation as people who did not read.
\end{abstract}

\begin{abstract}
In order to respond to problems of staff morale, recruitment and retention, in the last decade of the century attempts were made to make nursing more attractive by giving pre-registration learners student status, encouraging a research-based approach to learning and absorbing it into higher education. However many of the problems facing libraries would not be quickly resolved.
\end{abstract}

An attempt will be made to explain library provision for nurses with reference to the generation of knowledge in nursing and its relationship to library based knowledge. This will touch on the role and status of the nurse, the nature of her work and training, the ideological foundations of the nursing profession and the impact that these have on the provision of library services.

The main focus of this study is the period between the end of the 1950 s and the advent of the reforms of nursing education known as Project 2000 at the end of the 1980s. Most of the examples given are taken from England but similar conditions prevailed throughout the United Kingdom. At the beginning of this period there were relatively few libraries for nurses. Those that did exist were usually attached to Schools of Nursing and run by nurse tutors or clerical assistants. Despite the efforts of some nurse educationalists, library provision was poor for student nurses and, if anything, worse for trained staff. The reasons for this were to do with the apprenticeship nature of nurse education, the status of nurses within the professional hierarchy and the fragmented but bureaucratic nature of the health service. By the 1980s attempts were being made to tackle problems of nurse recruitment and retention by proposing that pre-registration learners should have student status within higher education. As a result nursing libraries would eventually move in name, and sometimes physically, into polytechnics and universities.

In order to provide some context to the period under review a brief survey of library provision for nurses follows. We will then look at the condition of nursing libraries, the services provided by them and how they were run.

Florence Nightingale herself seems to have valued libraries as institutions [1] and wrote that trainee nurses should be referred to 'books in their libraries' [2]. She advocated '[a] good Nurses Library of professional books, not for practitioners to skip and dip at random, but to be made careful use of under the medical instructor and the class mistress' [3].

Nursing librarianship has been described as 'an out of the way corner of library work' [4]. In the nineteenth century various nursing associations, nursing schools and larger 
hospitals set up their own collections [5]. There is little indication of how much use was made of these libraries but the library was 'evidently considered necessary and valuable' [6].

\section{The College of Nursing Library}

Even before the refurbishment of its central London base, completed in 2001, the Royal College of Nursing housed the prime nursing library in the UK, if not in Europe. The College of Nursing was established in 1916. Its library was not the first nor, with no more than three dozen books, the largest nursing library [7]. The first meeting of the College Library Committee took place in the College Headquarters in October 1921. The library was established with support of a grant from the Carnegie United Kingdom Trust. It became a specialist partner library of the Central Library, which was founded in 1916 to provide books for adult students. The College Library could borrow for its own students from the Central Library. The Central Library in turn handed over its own stock of nursing books, which was 'one textbook for nurses, four for midwives and 173 on medical and surgical subjects' [8].

The College Library opened on March 1st 1922 with 273 books and twelve readers; three months later there were twice as many books and 171 readers [9]. The Carnegie Trust made grants until 1926 when it stipulated that the College should allocate $£ 75$ of its own funds annually. The College Library underwent a much needed enlargement financed by the Halford Bequest. By the time it opened on 3 July 1945 non-College members were being charged an annual subscription and the first full time librarian had been appointed $[10,11]$. Books could be posted to individual members and training schools were provided with small book collections by post.

In 1949 Miss A.M.C.Thompson became Librarian, a post she held until she retired in 1968. Alice Thompson came to the RCN via posts with the BBC and St Marylebone public library. She would be a major force in developing library services for the College and for nurses in general, being involved in many of the developments which will be described below. Lizbeth Hockey, a noted nurse researcher, described Thompson as 'long-suffering and extremely helpful', 'refreshingly honest and forthright'. Miss Thompson introduced her to the meaning of 'searching the literature' [12].

\section{The link with education}

The establishment of the Education Department and post-certificate courses in the midtwenties had boosted the College of Nursing Library. In 1934 the Library Committee became a sub-committee of the Education Committee and the Library became part of the Education Department. Small numbers of post-certificate students began to attend the College and this gave an impetus to the Library's development [13]. With the encouragement of Miss Thompson there was a shift in emphasis 'from providing student nurses with library books from the central collection to promoting the establishment of libraries in their own nurse training schools' [14].

Pendrill did not think the nursing profession to be 'library conscious' [15]. If there was any pressure at all for library provision for nurses it came from educators rather than practitioners. In 1961 Godfrey Thompson, Deputy City Librarian in Manchester, summed up the situation to a group of nurse tutors: 'In many large hospitals in the United States, 
libraries have been considered essential parts of nursing schools for many years, and have had full time professional librarians to run them, but here you must be the librarians' [16].

Libraries that served the nursing profession were usually to be found in Schools of Nursing. Some in nurse education thought libraries to be 'an essential part of nursing education' [17]. In an article entitled Libraries in schools of nursing, Hilda Gration, described as 'formerly Sister Tutor, Guy's Hospital, London' notes that nurses in training are no longer called 'probationers' but 'students'. She wants tutors to encourage 'that enquiring attitude of mind which is so essential for true learning' [18]. 'When we talk of the possibility of our profession linking up with the universities', she asks, 'would our libraries impress the university authorities that we are educating our nurses on modern lines?'. (Gration's article was the first from a number of tutors in a series commissioned by the Nursing Times on the subject of libraries.)

Another nurse educator, Miss Dodwell, wrote that 'The library should be the pivot of all nurse training. It is the essential tool of the tutor and of the students' [19]. However, its use was seen as strictly limited. Altschul [20] expresses the wish that students will find the school library inadequate, thus giving the tutor the opportunity to direct them to other local and professional libraries. Surveying the scene in 1966 however, Miss Thompson, Librarian of the Royal College of Nursing, 'felt that there was a long way to go before the library was recognised as the key to a nurse's full education [21]. What is significant, however, is that there was a group of educators, people presumably committed to the project to professionalise nursing, who saw the library as essential to that project.

\section{Good and bad libraries}

Given that library provision for nurses was seen as important and in need of improvement, what was the typical nursing library like in the 1950s?

Although there is little in the way of statistical evidence, it seems that the issues that concerned Miss Tylor, of availability, relevance, supervision and exploitation of the library were still alive in the 1950s and 60's. Nursing libraries were primitive, 'the locked cupboard in the corridor with ancient texts was not unknown' [22] and may even have been 'the rule rather than an exception' [23]. The library 'is represented by a few tired books in a corner of a classroom or even in a cupboard in a corridor. ... invariably locked' [24]. While most tutors probably favoured open access, when the library would often be unattended, there was concern about pilferage [25]. (Wilkinson, writing in 1967, thought very few books went 'permanently missing' [26]. Miss Thompson, an advocate of open access libraries, noted this concern:

'Books must never be behind locked doors, and here, inevitably, we come up against a strongly rooted prejudice for, to the tutor, the loss of an $8 \mathrm{~s}$. $6 \mathrm{~d}$ copy of Squibbs' Aids to Materia Medica is a tragedy beside which the harm done to a student desirous of reading and confronted by a locked library door is as nothing [27].'

In some hospitals 'the 'library' consists of a shelf (or two) of textbooks, little used, out of date ...' [28]. Raybould, a nurse tutor at the Charing Cross and Fulham Hospitals School of Nursing, calls the library the most neglected part of the School of Nursing. 'All too often it 
consists of a handful of books, some out of date, a few very battered, and all locked away in a rather inaccessible cupboard; in fact many schools do not have a library in the true sense' [29]. Thornton, Librarian of St Bartholomew's Hospital Medical School, was of the view that there was 'not one adequate nursing school library with a trained staff in this country' [30].

Pendrill (1963) suggested there were only three substantial nursing libraries, apart from the RCN: St George's Hospital, Great Ormond Street and the Wolfson Training School at Westminster Hospital $[31,32]$. The Nursing Times featured a description of the nurses' library at St George's, London. It mentions the 'deep red carpet, ... olive green floor length velvet curtains, ...[the] well used and established air', the comfortable upright chairs for more serious study and note taking, the 'part-time librarian' and the view over Hyde Park. The accommodation and the catholic collection of over a thousand textbooks, monographs, biographies of famous doctors and nurses, and journals from the UK and abroad attracted the 'envious admiration of the medical students'. The article congratulated the authorities on their library provision 'often regarded as something of a side issue or a luxury, but ... surely ... a necessity in every training school', though even here '[t]he need for a bigger library has been apparent for some time...'[33].

Gration had given her view on what a library should be - warm, well lit, with study spaces and open shelves. She acknowledges, that '[i]t is more than likely, however, that the available accommodation is far from ideal' [34]. New books, journals and reports should be on display, the reference library should be accessible all day and the lending library open at 'convenient times'. There should be systems for reservations, fines and the classification, cataloguing and preparation of materials. It is suggested that '[a]ssistance with this may in the first place (my italics) be sought from a trained librarian, perhaps from a local library'. The librarian should be encouraged to promote the service to departments, to individuals, to committee meetings and to advertise services and acquisitions in residences, dining rooms and wards. There was a recognition that libraries were 'indispensable' for learners and nurses throughout their careers. However, while teachers supported the need for libraries 'their conviction was seldom supported by finance committees and others responsible for providing space, funds and opportunities' [35] and some tutors found 'a lack of sympathy among administrators for the very notion of a library' [36]. It should also be noted that much of a nurse's education was still based on an apprenticeship model which emphasised practical experience over academic study. There was little demand from prospective users for improved services. In an organisation where health care was the first call on funds, libraries and professional librarians might not be high priorities.

\section{Funding the library}

How were library services for nurses funded? Libraries in each nursing school were the responsibility of the principal tutor, who might delegate to a tutor, possibly assisted by a secretary. The tutor should normally be responsible for purchasing decisions [37, 38]. Morpurgo [39] found that many tutors had to prepare a list of proposed acquisitions a year in advance. Wilkinson, a principal tutor, confirms that there might be a wait of '12 or even 18 or 24 months for the expenditure to be approved, and it may be pared somewhat' [40]. This made it impossible to buy books quickly and meant that most books were at least a year old before they arrived in the library. A small committee including the librarian / tutor and possibly some nursing staff would report to the Nursing Education Committee in the 
School. This body would apply to one of the fifteen Area Nurse Training Committees (ANTC), set up under the Nurses Act (1949), for funds, which are allocated to it by the General Nursing Council, for a library grant. The process was slow and bureaucratic. A principal tutor described her experience: 'Estimates go every year to Matron, then to the Hospital Secretary, then to the Group Finance Officer and then to the Area Nurse Training Committee. My recommendations seldom get further than the Group Finance officer as the ANTC has usually made its allocation by then' [41]. The RCN had written to the Ministry of Health about the difficulty in getting funds for books but the allocation of funds was left in the hands of the ANTCs [42].

There was a range of funding levels. A Nursing Times survey of 19 nursing schools found the annual amount spent per hundred students varied between $£ 8$ and $£ 5510$ s [43]. The National Book League found 'a sensational variation' between schools in what they spent on books and journals [44]. 50\% of the 77 libraries they analysed spent less than 10 s. per student per year. A survey of nurse training libraries in the Wessex region found that three nursing schools on the Isle of Wight with 36, 70, and 27 students spent 7/6, 10/- and 15/- per student respectively on books and stationery. The average spent over the region was 9/- per student [45]. A survey in the West Midlands in 1966 also found 'a general inadequacy of funds for the purchase of text books in connection with nursing courses' with a great variation in funds available from one school to another [46].

Recommendations of how much should be spent on the library also varied. Thompson recommended 15/- per student per year and the Royal College of Nursing recommended $£ 1[47,48]$. H. B. Caie, Chairman of the Scottish Regional Committee Tutor Section of the Royal College of Nursing Scottish Board suggested 30/- [49]. In Wales most libraries were spending 'well below' what a Special Sub-committee of the Welsh Hospital Board 'considered necessary to maintain the very smallest library' [50]. The Nursing Times thought that the costs of libraries in national training scheme schools should be a charge on the Exchequer [51]. In practice no standard was applied centrally. The method of allocating funds meant that 'the finance which a nurse-training school library receives is in proportion only to the individual nurse tutor's persistence!' [52].

Nor was funding allocated in the most efficient way. Sometimes libraries would receive a windfall of money at the end of the financial year if the ANTC found some of its budget under spent. Although some money was better than none, this made efficient stock selection difficult and gave the impression that the library would only be funded when other needs had been met. It was not unknown for books to be bought from the stationery budget $[53,54]$. This was because, although ANTCs separated book and stationery allowances in their estimates, they combined them for purposes of allocation. This meant that because stationary would always be needed and the costs of stationary rose faster than book prices, funds allocated to books could be easily diminished [55].

The grant was not intended to be spent on textbooks, 'which the nurses themselves should possess, nor on works of fiction' [56]. In practice some libraries were stores for multiple copies of textbooks. 'The library in one school of 200 students consist[ed] entirely of between 16 and 20 copies of 16 titles [57]. The principal tutor concerned said that if she had more money she would buy more sets but in the latest editions. Libraries run by tutors could also be effective. For example, the Mile End Hospital library was 'one of the most efficient nurses libraries', an example of what could be done with limited funds but imagination and drive [58]. Loans were recorded by borrowers themselves, which was not untypical. It housed 1500 books, including items for general reading. The library had had 
its budget cut by the ANTC from $£ 100$ to $£ 65$ per year after a review of local nurse training libraries had found Mile End to be better off than most. Staff donated many journals or books.

Lorna Paulin summarised the situation for nursing students: '... of all types of hospital libraries it appears that the provision of an adequate service to student nurses has received the least attention. It is therefore in the provision of libraries for nurse training schools that rapid progress is particularly urgently needed, ..." [59]. Inadequacies and wide variations in funding continued through to the end of the century

\section{Services for trained staff}

If the situation was bad for students, if anything it was worse for qualified staff. Funding for trained staff libraries came from the Regional Hospital Board via the Hospital Management Committee [60]. Miss Thompson had found that libraries were usually open to trained staff but, even though publicised, this was rarely taken advantage of because nurses thought the libraries were 'sadly inadequate' and meant for students [60,61]. Also, after a full days work many did not want to visit the library. Although 'tradition on one side and prejudice on the other [meant that] nurses seldom have use of the medical school library' [62] there were exceptions to this rule, for example in Mansfield General Hospital [63] and the Royal Hospital, Edinburgh [64] where trained nurses could use the medical library. Nurses' use of the medical library was also permitted at Lincoln County Hospital [65]. The nurse training school collection there was stored in cupboards which tutors unlocked each day. The Medical Library, opened in 1963, boasted a subscription to Nursing Times and a trained librarian who would teach groups of nurses about library use. Although monies were derived from a variety of sources, for example ANTCs, boards of governors, and leagues of friends, the National Book League project [66] found that 'most trained staff use the students libraries and that funds from other sources do not have a significant effect on library expenditure'. A further reason for lack of funds 'could in most instances be ascribed to the absence of demand from the staff themselves' [67].

Aware of the problems of trained staff the Library of Nursing at the RCN placed its emphasis on their needs, arguing that students should be served by their training school libraries [68].

\section{Range of materials}

What materials were usually purchased for nursing libraries?

The figures quoted for library expenditure usually relate to money spent on books and journals. Bocock [69] suggested a list of books for starting a nursing library. The emphasis was on anatomy and physiology, medicine and pharmacology, and, of the nine nursing books, four were historical. In the mid 1950s because of a shortage of doctors and because of a gradual shift in nurse education towards a more theoretical and social studies orientation, nurses were beginning to take on additional responsibilities. This meant, as the RCN Librarian noted, that books for nurses 'now embrace a wider selection of medical texts than formerly' [70]. '[T]he content of nursing has become increasingly complex and words like 'research' and 'philosophy' now occupy the place in nursing terminology once held by 'poultice' and 'bandage" [71]. Gration suggests that a 'flourishing and well stocked' school library for 500 nurses would have 1000 books. Demand for books 
grows, she suggests, where there is an 'enterprising librarian' [72] Tutors were sometimes out of touch with the cost of books and, probably because of the way funding was arranged, slow to keep up with new editions [73].

H. A. C. Bishop, Principal Tutor at the Royal Northern Hospital in London, writing on planning the library, suggests the purposes for which books should be bought. She does not include the planning or undertaking of research, though she does see books as important for the acquisition of knowledge. For her, too, although the library might be in the nursing school, the assumption was that it would also provide for qualified staff [74]. She is quite clear that libraries should supplement texts that students will have bought for themselves, as are Worthy [75] and Altschul [76]. Materials are there to provoke thought, interest or constructive criticism and to provide 'literature which keeps abreast of current progress in an age when change is phenomenally rapid' [77]. The library should be purchasing a range of materials, for the novice and the advanced reader. 'Gone are the days' of rows of official textbooks, but 'books pointing to the practical application of knowledge, or about other people and their experiences, have a place' [78]. This approach was echoed in an article published over a decade later by the Principal Tutor at West Dorset Hospitals School of Nursing in 1967. Under the title Getting Nurses to use the Library Wilkinson concludes that a range of teaching techniques could be used to persuade the nurse 'to take books off the library shelves, and dip into them, and find her way about them, using the index wisely, ..., because she herself wants to know more, and knows how to find the knowledge for which she is searching in the written pages of other people's knowledge and experience' [79].

Libraries of course have to adjust their purchasing to the needs of their users. The Royal College of Nursing Library's bookstock had expanded to over 20,000 items by 1970. College syllabuses expanded to include aspects of not only nursing, medicine and health, but also sociology, psychology, social work and more besides. Some tutors looked to the library to provide material for a wider education [80]. Hutton estimated that around $20 \%$ of books borrowed from the library of the United Manchester Hospitals Nurse Teaching Department was 'fringe' reading, 'much of it sociologically oriented', material described as not needing their full attention and 'suitable for such periods as night duty' [81]. Writes the RCN Librarian: 'nurses' interest in management following the Salmon Report in 1966, the growing concern with the art of examining, the role of the assessor and the technique of interviewing, the use of computers and particularly the growing volume of nursing research have all had their effect on the character of the Library' [82].

Bishop also recommends journals, both medical and nursing. They provide 'knowledge of progress, research, modern treatments and, of course information relating to professional trends, opinions and controversy, so important if nurses are to be effective members of a professional organization' [83].

The Royal College of Nursing also published a guide entitled A library guide for schools of nursing (RCN 1962), which covered stock, finance, accommodation, equipment and organisation of libraries. In addition to the practicalities of running a library - it was aimed at nurse tutors rather than professional librarians - it also had things to say about the role of the library in the profession. According to the author of this guide (probably Alice Thompson), it is the library which provokes thought in the nurse, by providing the link between 'what she has been told in the classroom with what she does on the wards'. It enables her to obtain information and build up an organised body of information. 
Furthermore, the guide states that '[o]f all the criteria of a professional education, none is more important than a good library, and it is often the most disregarded. The library should be the hub of the school, the centre of educational activity ...' [84].

Morpurgo found that many tutors wanted libraries to include more than nursing texts. They found that nursing students were often not academically inclined; the nursing school was the last opportunity to make good the defects of their earlier education [85]. Nurse education was based on a system which meant that staff and students were too busy to read, 'a pattern of training which stultifies and discourages the expression of critical thought' [86].

\section{Running the Library - Nurse tutors as librarians}

Most hospital libraries were run by volunteers, usually under the auspices of the St John Red Cross. Library facilities were more likely to be available for patients than staff [87]. In nursing schools the librarian would probably be a nurse tutor, who would have little or no library training.

In April 1961 a weekend course on The use of books and libraries in the training of nurses took place in Manchester. Attended by 54 nurse tutors its aim was to 'encourage tutors to improve the present libraries in schools of nursing and to give them practice guidance'. It was organised by the Manchester Area Nurse Training Committee, who had been 'appalled' by the small amount spent on libraries. One hospital of 130 beds was spending $£ 10$ a year on its library. Over the whole region $£ 4000$ was being spent on 4000 students, and pupil and trained nurses in addition. The only criticism of the course was 'why have we not had such a course earlier' [88, 89].

The Manchester course was also concerned with the idea of encouraging nurses to read in order to widen their horizons and because 'it is of very vital importance for the future of medical care in the widest sense that nurses should have access to information on all aspects of their profession and that they should want (author's italics) to consult it' [90, see also 91]).

The RCN's Library guide for schools of nursing (1962) was published with nurse tutors in mind. The National Book League survey [92] found that many had read the Guide but Miss Thompson, commenting on the League's preliminary findings, felt that this 'illustrates the point that while the profession plays lip service to the improvement of libraries comparatively few tutors are prepared actively to bring this improvement about.' [93].

By way of illustration of this point, J. S. Fenn, a principal tutor, described how she built up the Victoria and Kilton libraries in Worksop. In 1963 the library was a locked cupboard containing about 100 books, many out of date. It stood in the principal tutor's office and was accessed by making an appointment and signing a register. By 1968 there was a collection of 400 books. She liaised with the city librarian who agreed to buy nursing books for the public library if the nursing library ran out of money. She hoped to employ a secretary to issue books when the tutors were not available. Fenn thought there would be some who would doubt the sense in trying to improve or change the established order but she is an enthusiast who would 'recommend any tutor whose library is antiquated to have a go at building it up' [94]. 
An annual course for Sister Tutors began at the RCN in 1963 and included instruction in the use of books and library organisation [95]. According to Frances Walsh, Miss Thompson's successor, 'these courses helped to stimulate in the nursing profession an awareness of the potentialities of libraries, particularly in the field of nurse education' [96].

\section{The role of the professional librarian}

Some tutors thought there was a place for a professional librarian in the nursing school library. This was a belief encouraged by Alice Thompson. She thought that only a wellstocked library could foster 'the creative imagination, the sensitive spirit, and the intelligent understanding' without which, in Isabel Stewart's words "nursing may become a highly skilled trade, but it cannot be a profession or fine art" [97]. A library was vital to the creation of an integrated personality developed through a critical and enquiring mind. $A$ joint medical / nursing library was the 'ideal' [98].

She did appreciate that most libraries for nurse training were too small for a full time librarian and that expense would probably preclude employment of professional librarians at most school nursing libraries. However, advice could be taken from local authority librarians or a group of training schools might make a joint appointment. (A survey of 102 public library authorities by the Library Association in 1966 found that 23 provided professional literature for nurses, 22 provided professional literature for nursing students, 18 provided literature for doctors and nurses, 25 for doctors only and 20 for other hospital staff [99]. Where money could be found there was a role for the professional librarian, a person 'who is trained to make books and information quickly and conveniently available, and who can stimulate a student's interest in further reading [and] who should not be considered a luxury' [100]. It was considered worthy of report in the Nursing Times in 1965 when Mrs Elek was appointed as full-time professional librarian to the Royal Free Hospital School of Nursing. This was the first post of its kind to be approved by the North West Metropolitan Area Nurse Training Committee and the GNC [101].

In the comments of Alice Thompson we can see the link between nursing as a profession and the library as an access point for the various kinds of knowledge utilised by nurses.

'The growth of a profession may be measured by its literature, but what of its libraries? There is not, apart from the Library of the Royal College of Nursing, any professional library for nurses. We are left with the libraries of nurse-training schools, and there we have a sad story. Nurse-tutors do not always remember that they are members of two professions, that they are teachers as well as nurses, with all the responsibility of the teacher for the moulding and developing of the young adult mind. Teaching falls short of its purpose if it does not set the student thinking on her own account, linking what she has been taught in the classroom with what she does on the wards. That the link may be found in a library is not yet fully appreciated' [102].

Mr Thornton considered that all hospitals should recognise the need to provide libraries for nurses and other medical staff. He spoke of the need for 'professionally trained staff who would be able to adequately exploit the small stock and know the various ways of obtaining works from other libraries, especially in co-operating with any special libraries in the area' [103]. 


\section{Standards for Hospital Libraries}

Miss Thompson's view of the National Book League survey was that at least 'it will show up only too plainly the deficiencies of these libraries' [104]. In commenting on the interim report she found 'alas, no finding in this report which was not already known' [105]

In view of the general level of health library provision, the Hospital Group and Medical Section of the Library Association formed a joint sub-committee to propose standards for library provision in hospitals. A major building programme of new hospitals had prompted this. 'Hospital libraries: recommended standards for libraries in hospitals', published by the Library Association in November 1965, has been described as 'probably the most important single document to have been published so far in this country on hospital libraries' [106]. The recommendations proposed services for a wide range of health service employees, including trained and student nurses. They do not differentiate between services for doctors and nurses but see the split as between professional and recreational literature. They suggest 'that two libraries should be the maximum necessary in any hospital' [107], one for 'curative' staff, the other mainly providing for patients' rehabilitation and recreation. A single professional library under the care of a professional librarian is an ideal. The report states that 'as long as the present form of nurse training prevails and while the student nurse forms the chief labour force of the hospital, the nurse training school will continue to need its own specialist library situated in the training school itself' [108]. Reflecting Alice Thompson's membership of the Committee which drafted the standards, the library was 'the axis on which ward practice and classroom theory turn' [109].

The LA were not alone in making recommendations for standards. The Ministry of Health's Equipment Note 14 on nurse training schools [110], the National Book League survey and the Royal College of Nursing's Library guide for schools of nursing all give differing recommendations for levels of funding, for example.

More explicitly the LA states that the term "nursing library' means the library in the nurse training school used exclusively by student nurses' [their italics] [111]. Exclusivity would rarely be the case in practice, because in many places trained nurses would not be allowed to use the medical library so they would have to use the nurse training library. Another reason was that the school library might be away from the wards, which sometimes had their own collections of books. For example, in Pembury Hospital, Kent, '[the] medical library is distant and the nurse training school with its library is yet further away' [112]. The day to day running of the nursing school library is assumed by the LA to be in the hands of the principal tutor, responsible to the school education committee. The librarian, if there was one working in the medical library, should consult and advise on the running of the nursing school library. The assumption was that the nursing library, whoever it served, would be too small or inferior to warrant a librarian of its own. Perhaps if the LA had been more assertive in calling for professional librarians in nursing libraries, things would have improved more quickly.

Not only the Library Association was suggesting an integrated nursing/medical library service. The Final Report of the Working Party on Medical Libraries set up by the Medical Committee of the Sheffield Regional Hospital Board (SRHB) quoted from a 1957 report of the Committee on Hospital Library Architecture of the United Hospital Fund of New York to 
the effect that combining nursing, medical and patients' libraries improved service, was more efficient, economised on space and saved duplication of books journals, equipment and staffing [113]. A survey of the Oxford Region came to a similar conclusion [114]. The Sheffield Report thought that medical libraries should also serve nurses, and others, and that guidance should be given in library use. Although talking about medical research, the point was also made that neither education nor research could flourish without libraries.

A survey of library services in the hospitals of the South East Metropolitan Regional Hospital Board also favoured integration of all library services to hospital staff. It also indicated that a full library service for nurses was the exception rather than the rule. 128 hospitals responded to a questionnaire, a $75 \%$ return. 105 said they had library services, 42 provided reference and textbooks to nurses and 9 provided enquiry and information services for nurses (compared to 10 for doctors). The report concluded that 'only in recent years' had much thought been given to providing libraries for staff in hospitals and that librarians should 'assist in the formation and maintenance of nursing libraries' [115].

In February 1966 a Conference was organised by the Hospital Centre and the Library Association to discuss the LA's standards. Miss Thompson described the slow development of the nursing profession which had been hindered by the illiteracy of its early membership and the suspicions of doctors. The development of libraries reflected this and she mentioned the tendency to put service provision before education, and the nursing attitudes of being too busy to read and that reading equalled 'idleness' [116].

A second speaker to discuss nursing libraries was Miss B. Dodwell, Principal of the Queen Elizabeth Hospital School of Nursing in Birmingham. She was on record as describing the nurse training library as 'the Cinderella in the majority of nursing schools in the country today' [117]. She outlined the typical scenario of libraries as locked cupboards, in studies and classrooms. She indicated, as had Miss Thompson, that hospital authorities were unwilling to accept responsibility for trained staff and needed continuing investment not just single capital grants. Miss Dodwell thought integrated libraries could overlook nursing needs. Like other speakers on the day, she thought a properly trained librarian should run the library not a part-time tutor or volunteer [118]. The Library Association's representative felt moved to extol the efforts of such people. Several speakers also spoke about medical library provision. It was mentioned that the Sheffield and Wessex Regional Hospital Boards had or were appointing regional librarians to co-ordinate library provision for all staff and patients as recommended by the Sheffield and Wessex reports [119].

In 1972 the Libraries Association published a second edition of its standards for libraries in hospitals [120]. While welcoming the effort one reviewer stated that it was still necessary 'to state simple facts for those in hundreds of hospitals which muster few library resources' [121]. In 1978 and 1980 revised Guidelines were issued [122]. Though useful as a standard where libraries existed, in the many hospitals where they did not, the LA's guidelines were probably largely irrelevant.

\section{Research}

Researchers contribute to the body of knowledge. An extensive body of specifically nursing literature has only begun to develop since the 1950s. In the 1960's hospitals became centres for health science education and research. However, compared with 
industry or business, research library and information services in the health service were 'primitive and scarce'; 'Indeed basic bibliographical services are rarely understood by the medical and nursing professions' [123]. There are few references to nursing libraries being used for research purposes. However, the librarian of the Royal College of Nursing stated in 1969 that the growing volume of research, among other things, had affected the character of the library and that 'so much nursing research is being conducted today, in such a wide variety of institutions that it is difficult to keep ... a register [of on-going research in nursing] up to date' [124].

Access to literature through a library would not have been easily available to all nurses. The government set up the Committee on Nursing in 1970 under the Chairmanship of Asa Briggs. It was to 'review the role of the nurse and the midwife in the hospital and the community and the education and training required for that role...' [125]. The Committee's Report stressed the need to improve library provision for students and trained staff:

'We regard as indispensable the raising of the standard of College libraries so that they become comparable with libraries which serve the training needs of other professions. Trained librarians should be appointed where possible. The facilities of the library should be available for use by qualified nurses and midwives and by nursing aides as well as students' [126].

Briggs called for adequate financial provision for books, journals and other library services. He also saw the importance of libraries for research.

'A greater measure of research-mindedness within the profession could be fostered during pre-Registration education by, for example, ensuring that every nurse and midwife can use a library adequately, by employing problem solving and project techniques in teaching, by referring in teaching to research findings and reports, and specifically by encouraging nurses and midwives who show an interest in research procedures' [127].

As a partial response to the increasing interest in nursing research the DHSS Library instigated the Index of Nursing Research (INR) in 1975. This used information collected by Nursing Officers in the Research Division of the DHSS. From the INR grew a regular publication, Nursing Research Abstracts in 1978. A retrospective volume was published for the period 1968-1976. After 1983 the INR was also incorporated into the online database of the DHSS Library, DHSS-data [128].

\section{Towards Integration}

In the 1970s professional library opinion favoured, if not full integration of medical and nursing libraries, then co-operation, if only to ensure best use of staff and stock.

Briggs put his weight behind this view. 'Where circumstances are suitable, the resources of the College library should be combined with those provided for other professional health staff working in the hospitals and the community' [129].

Pattinson carried out a review in the Cheshire Area Health Authority in 1974 with a view to improving and co-ordinating library and information services. The needs of researchers and managers were seen to be particularly poorly catered for. There was little evidence of usage by trained staff or community nurses. There were no qualified librarians. He 
recommended that nursing and related literature should be available in hospital libraries where medical and nursing material should be integrated [130].

In some areas nurses were lucky enough to be able to use a range of libraries. At the Queen Elizabeth II Hospital in Welwyn Garden City student nurses could use the general and the medical libraries, as well as their small nursing library, because of the range of topics they studied [131]. At the Lister Hospital, Stevenage, the libraries co-operated. Teaching staff at the School of Nursing there were library orientated and treated the library staff as equals [132]. Right of access did not solve all problems. 'Nurses have always, however, been the poor relations seldom allowed access to these libraries - even in the enlightened areas where they were permitted to use the library their needs were not always represented in the stock' [133].

Although some reports were still concerned mainly with medical libraries, there was a growing recognition that nurses' library needs could not go on being ignored.

It would seem wisdom for the future to consider the possibility of the inclusion of nurses libraries within the system. Integrating their libraries with the Hospital Libraries and PGC [Post-Graduate Centre] libraries thus reduces the isolation of this para-medical group, offering improved library services to them, and making optimal use of library staff [134]

This was part of a report, which sought to bring together services for health service staff in the West Midlands region. Improvement of services would continue to be slow [135]. The Wessex region, of which Tabor was writing, was one where services were provided for all staff. Wessex had a policy of working towards an integrated regional service.

Incorporating a nursing library into the main NHS library would lead to savings in costs and space and a wider range of material being available for nurse education [136]. The County librarian of Gwynedd described a more typical situation. He found that there 'must have been too long a time when library expenditure in schools of nursing was inadequate'. He was particularly concerned that nurses should have access 'not only to their nurse training school library, but also to the general hospital library' [137].

Although administrative integration of library services had been favoured by the Library Association's 1965 recommendations for standards in hospital libraries, progress was patchy. According to a library student 'the major enemy is financial stringency and the apparent apathy of the powers-that-be' [138]. Pattinson's wider ranging view was that cooperative medical library services were likely only where the value of such a service was recognised, it had the support of local managers, and had effective financial and administrative support [139].

The funding of many libraries continued to be inadequate, particularly for trained staff, who usually used School of Nursing libraries. A survey of 20 Scottish College of Nursing Libraries found that only one received regular funding for trained staff, although others received occasional windfall payments, usually at the end of the financial year.

\section{Isolation}

There was a danger that staff working in nursing libraries in the health service could be isolated. Firstly nurses were not used to working with non-medical professionals. They were used to getting their information from colleagues rather than a library. Librarians 
could also be isolated professionally, working alone at some distance from others. Although the job was rewarding, pay and conditions were poor, the workload could be heavy and there was no career structure. Consequently staff turnover tended to be high. One Scottish site had six post holders in eleven years. There was a feeling that if libraries were to develop their educational role, if librarians were to be able to have the knowledge to support a range of courses and develop area responsibilities, there would need to be an upgrading of the role, specifically from General Administrative Assistant to Senior Administrative Assistant [140].

As we have seen, budgets varied depending on the priorities of the local Area Nurse Training Committee and the negotiating power and interests of the Principal. Librarians were usually free to order materials but sometimes had to work through committees and deal with cumbersome central ordering procedures. Some had to work with no budget or were expected to buy materials without knowing how much in total they had to spend. Often windfall money would arrive at the end of the financial year and have to be spent within a few weeks. In the 1950s there was relatively little British material available. Most texts were American and not always appropriate.

1980 saw the publication of the General Nursing Council's Circular 80/12 on Library Services. (The GNC was the body that lay down standards for training institutions). This document presented the library as 'the natural focus of 'research-based' practice' [141]. Libraries provide access to the knowledge base of clinical practice and to past experience and knowledge which can inform management decisions. They should stock a range of materials and resources, including computer databases and inter-library loans. The circular argued for integration of services at a district level and for sharing of provision for trained and student nurses so that both groups should 'develop the library habit' and 'positive attitudes to the use of information' [142]. The GNC's positive approach to libraries, at least on paper, indicated the enthusiasm of some senior nursing professionals for libraries but it would be misleading to suggest that these demands were matched by improvements in services or resources. Indeed the GNC failed to set its inspectors clear standards by which to judge libraries in the training establishments, which they accredited. (This same criticism would be levelled at the GNC's successor, the English National Board for Nursing, Midwifery and Health Visiting).

By 1980 some Regions were beginning to organise libraries and appoint librarians on a Regional basis. Wessex, Oxford and the two South Thames regions had begun to organise in this way, though the emphasis was more medical than nursing. In 1979 a two year scheme funded by the Regional Health Authority began which allowed qualified staff access to the Newcastle Polytechnic Library, one of the best nursing collections in the country [143]. By August 1981 they had 1550 registered borrowers. Information skills teaching was carried out with some nurses in the area.

It was still rare in 1980 for Schools of Nursing libraries to employ professional librarians. They were open limited hours and did not usually participate in inter-library loan schemes. A survey of 12 nursing libraries in the North West Thames region found that '[a]lthough they were all serving the training needs of nurses, having no standard guidelines, the libraries had developed independently over the years and the great disparity of provision was noteworthy' [144]. It was a criticism of the time that developments depended on local initiatives rather than central direction from the GNC or the DHSS [145]. 


\section{Overcoming isolation}

Librarians were keen to work towards improving provision for nurses and to overcome their isolation. In the 1970s a Study Group on Information for Nurses consisting of researchers, nurse educators and librarians was formed. In Scotland librarians began to meet regularly under the auspices of the Royal College of Nursing, initially from 1973 as the Advisory Group on Libraries in Schools of Nursing and from 1975 as the Association of Scottish Health Sciences Librarians (ASHSL). At the Annual Conference of the Medical Health and Welfare Librarians group of the Library Association (MHWLG) in 1980 a meeting was held for librarians who provided services for nurses with a view to establishing a sub-section for this 'ever increasing' group. In 1978 only $29 \%$ of staff working in Schools of Nursing libraries were qualified librarians [146]. It was proposed that the MHWLG establish a sub-section for this professional group and the meeting unanimously accepted this suggestion.

A Working Party was set up and decided the new group would be called the Nursing Interest Sub-Group (NISG). Some 80 people attended the inaugural NISG meeting in November 1980 at the King's Fund Centre. The rules of the sub-group were aimed at including nurses and secretary/librarians. However non-members of the Library Association, for example nurses, would only be allowed to attend certain open meetings. The objectives of the NISG as outlined in their rules would be :

1) To provide a focal point for professional contact and discussion amongst qualified librarians/members of the Library Association serving nurses

2 ) To promote a dialogue between nurses and librarians and a greater understanding of the roles and functions of the two professions.

3 ) To bring together periodically all persons involved in the provision of library and information services for nurses.

The sub-group soon began to produce a regular newsletter and held a study day, the first of many, entitled 'Users Speak' in March 1981. Speakers came from universities, colleges of nursing, the professional press and the Department of Health and Social Security. They emphasised the changing nature of the nursing profession, the aim of making nursing a research based profession, the need to involve librarians in providing services to students and nurses on wards and in nurse education, and on the value of combining libraries for all health professionals. The NISG served for the first time to bring together otherwise isolated nursing librarians, to encourage the development of Regional directories of staff and lists of journals, and to further the education of librarians through a series of study days [147].

\section{Moving nurse education into higher education}

In January 1982 the United Kingdom Central Council for Nursing, Midwifery and Health Visiting (UKCC) Working Group 3 produced a consultation document on the development of nurse education. (The UKCC was the body responsible at this time for the standard of nurse training). The NISG response was that libraries could contribute towards nurse education but they needed to provide services for all nurses, not just those in training. Libraries should hold a full range of resources, and be able to draw upon Regional networks. Nursing librarians should be professionally qualified, members of the education 
team and provided with administrative support. Nurse education required the support of a 'comprehensive, adequately funded, library and information service' [148].

In May 1983, as one of a series organised by the Regional Librarians Group and the DHSS Working Party on Library Services, a meeting was held on the library needs of the nursing profession. Discussions occurred under the headings of research, education, practice and management. Problems identified were the scatter of nursing knowledge across a range of subject areas, the difficulty that small libraries have holding relevant material, the need for effective indexes of the literature and access to a range of library resources, the need for libraries to educate their users and promote their services more, and the need to identify sources of funding for practising nurses, researchers and managers. The feeling was that health libraries should be multidisciplinary and encouraged to share resources. This approach did have its critics. There were fears for the autonomy of nursing schools and that nursing interests would be swamped by those of doctors. The meeting also noted that many practising nurses were not really interested in libraries. 'The qualified practitioner, except when involved in post-basic courses, is not usually a heavy, library user. Lack of use can be attributed to a combination of apathy on the part of the nurse, lack of knowledge of how to use libraries, limited opening hours, inappropriate services and a lack of publicity for services' [149].

The series of joint DHSS/RLG meetings culminated in a document entitled Converting Information into care [150]. This proposed that all library services within a district should be administered as one service with the aim of meeting the needs of all staff groups within the district. The district service would work within a co-operative, supportive regional and national network. The specific issues identified as relating to nurses were to facilitate the exploitation of facilities for educational purposes, to be proactive in encouraging use by clinical nursing staff and promoting awareness of services, and the need to offer a range of indexing sources and develop use of interlibrary loan services in the support of research.

1984 also found many libraries subject to cuts in their book and journals budgets as part of wide ranging cuts in the health service.

In 1985 the document Providing a District Library Service, a RLG, DHSS, King's Fund production, was published. This was derived from the Converting information into care document. By this time there were proposals to reorganise nurse education. On the one hand this meant that the report made little direct comment on library services for nurses. On the other, it was again clear on the eve of nurse education moving into higher education, via what was known as Project 2000, that libraries which were to support nursing students and their trained colleagues could still be described as causing 'concern', being 'poor' or 'non-existent'. Levels of provision across the country were 'uneven', funding could be 'irregular' and staffing levels were 'very poor' [151].

\section{Explaining the state of nursing libraries}

Many inter-related factors contribute to explaining the state of nursing libraries in the second half of the twentieth century.

Although Florence Nightingale valued libraries many nurses in her day were poorly educated, if not illiterate. Tylor's early investigation of libraries implied that nurses did not 
use libraries even when they were provided. The apprenticeship nature of nurse training operated against interest among nurses for reading. Training or qualified, nurses work hard physically and emotionally, and they may be too tired to read, or the library, if it exists, may not be open during their shift. Nurses, in Virginia Henderson's words, are not 'bookish people' [152]. Bunch and Cumming [153] note that 'once qualified most nurses have been content to practise their skill without reading anything further about it; nurses have not had the opportunity to become book conscious'.

Knowledge, however, comes in different forms and traditionally nurses did not acquire their knowledge or pass it on via the written word. Nursing is often seen as a vocation, a set of skills and procedures to be learned, emotional labour rather than theoretical knowledge. Knowledge is acquired through experience or the experience of colleagues [154]. The view of one librarian was that 'within the nursing profession as a whole, there always seemed a reluctance to accept that libraries were necessary' [155].

This view was almost certainly true of some, possibly a majority of nurses. White [156] and Dingwall, et al, [157] have identified groups within the nursing profession in the second half of the twentieth century. Rosemary White presents nursing as a divided community made up of three groups: generalists (e.g. clinical nurses), specialists (e.g. nurse teachers) and administrators (e.g. managers). The better educated or more intelligent would seek to improve their position through post-registration courses, specialising, moving into nurse education or administration. The less ambitious or less able remained on the wards, favouring practice, tradition and ritual, sometimes developing an anti-education ethic. It may be that the slow development of nursing libraries in this period is a reflection of tensions within the occupation, with some seeking to professionalise through education and research and others who wish to derive the nursing knowledge base from vocational experience.

One result of these tensions may have resulted in the lack of a substantial research base for nursing knowledge, a lack of written material and a consequent lack of need for libraries. This would not be an argument which could be defended at the end of the century. There is also an element of chicken and egg in this suggestion. If library provision for nursing has been poor, has this been because there has been a lack of research generated knowledge for nurses to use or because the way that nurses generate their knowledge is not written up? Or has nursing been slow to generate a research derived knowledge base because there are inadequate libraries to organise, make it accessible and assist in disseminating it? The Briggs Report certainly saw a link between the need to encourage nurses' awareness of research and their use of libraries.

Nursing libraries also suffered to some extent from the status of nurses within the health service. In the middle of the century they were still seen as handmaidens of doctors. This status found its way into the provision of facilities for them. At the extreme this is reflected in the perceived lack of need for nurses to upgrade their level of knowledge and the fact that where library facilities existed for doctors, nurses were often not allowed to use them. While nurses might benefit from economies of scale inherent in multidisciplinary or integrated libraries, doctors sometimes opposed such libraries. It is also the case that medical education and its libraries were linked to universities whereas nurse education took place largely within the health service. The nurse - doctor status relationship was sometimes echoed in the relation of medical librarian to nursing librarian as the latter sought to establish themselves [158]. 
There were nursing professionals who wished to move nurse education away from an apprenticeship / training model to a more investigative / educational approach and thereby encourage library use. There were also librarians working at national, regional and latterly at site level, eager to promote awareness and use. Their work expressed itself through guides, conferences, recommended standards or guidelines for provision, and through organisations like the Library Association's groups and sub-groups and their publications. These sought to bring together and inform professional librarians, nurse tutors, other library workers and sometimes nurses themselves in order to improve and develop services.

The second half of the twentieth century saw changes in library provision for nurses. The ubiquitous 'locked cupboards' seemed to disappear but there were considerably fewer institutions training nurses by the end of the century so resources did not have to be spread quite so thinly. The move into higher education in the nineties would serve to highlight the lack of provision there had always been for qualified staff not undergoing education, so issues of funding and access did not go away. What remained true was that the quality and level of library provision varied across the country and between districts which serves to remind us that whatever the reports or the guidelines say, there is still a lot to be done and it is for librarians, working with academics, health service managers and nursing colleagues, to do something about it.

This article is based on a paper originally delivered at the $8^{\text {th }}$ International Congress on Medical Librarianship, July 2000

\section{Acronyms}

ANTC Area Nurse Training Committee

ASHSL Association of Scottish Health Sciences Librarians

DHSS Department of Health and Social Security

GNC General Nursing Council

HLHRG Hospital Libraries and Handicapped Readers Group

INR Index of Nursing Research

LA Library Association

MHWLG Medical Health and Welfare Librarians Group

NISG Nursing Interest Sub-Group

RCN Royal College of Nursing

RLG Regional Librarians Group

SRHB Sheffield Regional Hospital Board

UKCC United Kingdom Central Council for Nursing, Midwifery and Health Visiting 


\section{References}

1. Calabria, M D (1994) Florence Nightingale and the libraries of the British army Libraries and Culture 29(4) 367-388

2. Parr, L. J (1980) Early libraries for nurses in England, 1860-1914 Journal of Librarianship 12(2) 110

3. Baly, M (ed) (1991) "As Miss Nightingale said..." Florence Nightingale through her sayings: a victorian perspective London:Scutari 92.

4. Tylor, D (1895) Hospital libraries The Library vii(83) November 351

5. Parr op cit. 110-112

6. Tylor op cit. 350

7. Parr op cit.. 109

8. Gillespie, S. (1981) 'The nursing profession' IN Carmel, M (ed) Medical Librarianship London : Library Association 22

9. Nursing Times (1951) Library for Nurses 47 April 7, 341

10. Seymer, L C (1957) A general history of nursing, 4th ed. London : Faber \& Faber 192 11. Walsh, F. M. (1970) The library of the Royal College of Nursing and National Council of Nurses of the United Kingdom Book Trolley 2(12) December 4-8

12. Hockey, L (1985) Nursing research: mistakes and misconceptions Edinburgh :

Churchill Livingstone 12-13

13. Walsh op cit. 4

14. ibid 5

15. Pendrill, G. R. (1963) 'Medical libraries and medical literature' IN Sewell, P. H. (ed)

Five years work in Librarianship 1956-1960 London : Library Association 51

16. Thompson, $G$ (1961) The value of books and libraries to the nurse: 1 . Reading for professional reasons Nursing Mirror 16 June 1030

17. Seymer op cit.

18. Gration, H. M. (1955) Libraries in schools of nursing Nursing Times 51 March 18 282

19. Dodwell, B. I. R. (1965) The library in the nurse training school Book Trolley 1(2) June 6

20. Altschul, A (1955) In a mental hospital Nursing Times 51 April 22434

21. Book Trolley (1966) Hospital Centre Conference 1(5) March 6

22. Tabor, R. B. (1979) Professional knowledge and the nurse Nursing Times 75

November 151983

23. Pendrill op cit. 51

24. Thompson, A. M. C. (1962a) 'Libraries in hospitals: (I) Libraries in nurse training schools' IN Library Association, Proceedings, papers and summaries of discussions at the Llandudno conference London : Library Association 44

25. Nursing Times (1960) Libraries in 19 schools of nursing 56 June 3689

26. Wilkinson, P (1967) Getting nurses to use the library Nursing Times 63 February 10 187

27. Thompson, A. M. C. (1962b) Libraries in nursing schools 1 Nursing Times 58 August

241091

28. Gration op cit. 282

29. Raybould, E (1964) Building a nursing school library Nursing Times June 5724 
30. Thornton, J. L. (1962) 'Libraries in hospitals: (2) Medical libraries in hospitals' IN Library Association, Proceedings, papers and summaries of discussions at the Llandudno conference London : Library Association 48

31. Pendrill op cit. 51

32. Thompson (1962a) op cit. 45

33. Nursing Times (1958) The library for nurses at St George's Hospital, London 54 April 4 390-392

34. Gration op cit. 283

35. Morpurgo, J. E. (1966) Book and Journal services for doctors and nurses: an interim report on a National book League investigation London : Nuffield Provincial Hospital Trust 9

36. ibid. 34

37. Thompson, A. M. C. (1960) The training school library Nursing Times 56 June 3 703

38. Nursing Mirror (1961) The use of books in nurse training 28 April 333-334

39. Morpurgo op cit. 34

40. Wilkinson op cit. 187

41. Morpurgo op cit. 34

42. RCN (1964) Minutes of a meeting of the RCN Hospitals Department, Tutor section, Central Sectional Committee 24/4/64 (RCN archive)

43. Nursing Times (1960) op cit.

44. Morpurgo op cit. 31

45. Royal College of Nursing and National Council of Nurses of the United Kingdom (1966) A report, with recommendations, of a survey of library provision for nursing and midwifery staff within the area of the Wessex Regional Hospital Board [unpublished report by Alice Thompson, copy in RCN archive] 6

46. Library Association West Midlands Branch (1970) Library services to hospitals and handicapped people LAWMB 4

47. Thompson, A. M. C. (1962c) Libraries in nursing schools 2 Nursing Times 58 August 311117

48. Royal College of Nursing Library (1962) A library guide for schools of nursing London : RCN

49. Caie, H B (1962) Letter to Miss Wilson, Registrar General Nursing Council of Scotland 7th November 1962.

50. Book Trolley (1968) Library services : Welsh Hospital Board. Report of the Special sub-committee on library services 2(1) March 12-18

51. Nursing Times (1960) op cit.

52. Bunch, A. J. and Cumming, E.E. (1969) Libraries in hospitals : a review of services in Scotland Edinburgh : Scottish Hospital Centre 39

53. Nursing Times (1960) op cit. 689

54. Tabor op cit. 1983

55. Morpurgo op cit. 32-33

56. Gration op cit. 283

57. Morpurgo op cit. 36

58. Nursing Times (1966b) Mile End Hospital 62(29) July 22967

59. Paulin, L. V. (1965) Recommended standards for libraries in hospitals Book Trolley 1(4) 3

60. Thompson (1962a) op cit. 44

61. Stapleton, M (1983) The educational needs of trained nurses Nursing Mirror October 26 40-41 
62. Thompson, A. M. C (1965) A sense of values Nursing Times 61 June 14735

63. Boorer, D (1965) Libraries for nurses 1: Mansfield General Hospital Nursing Times December 10 1688-1690

64. Tait, L (1965) Library Services 2 - The Edinburgh Hospitals Book Trolley 2(4) December 6-7

65. Boorer, D (1966) Libraries for nurses 2: Lincoln County Hospital Nursing Times April

15 505-507

66. Morpurgo op cit. 32

67. Book Trolley (1968) op cit. 17

68. Walsh op cit. 6

69. Bocock, E.J. (1955) Starting a school of nursing library Nursing Times 51 March 25 320,330

70. Quoted by Pendrill op cit. 51

71. Thompson (1962a) op cit. 44

72. Gration op cit.

73 Nursing Times (1960). op cit.

74. Bishop, H. A. C. (1955) Planning the library: Why? And how? Nursing Times 51 March 18284

75. Worthy, E. J. (1955) In a Paediatric hospital Nursing Times 51 April 15 409-410

76. Altschul op cit.

77. Bishop op cit. 284

78. ibid

79. Wilkinson op cit. 188

80. Morpurgo op cit.35

81. Hutton, J. M. (1967) Library provision for the modern nurse Nursing Times 63

December 11616

82. Walsh op cit. 7

83. Bishop op cit. 285

84. RCN 1962 op cit. 5-6

85. Morpurgo op cit. 35

86. Thompson (1962a) op cit. 45

87. King Edward's Hospital Fund (1959) Hospital library services : a pilot survey London :

King Edward's Hospital Fund 34-37

88. Dodwell, B. I. R. (1961) Books and libraries in nurse training Nursing Times 57, April 28519

89. Nursing Mirror op cit.

90. Thompson (1961) op cit. 1030

91. Sullivan, J J (1961) The value of books and libraries to the nurse: 2 . Reading for personal reasons Nursing Mirror 16 June 1133-1134,1139

92. Morpurgo op cit.

93. Letter from Miss Thompson to National Book League 14/12/65 (RCN archive)

94. Fenn, L. J. S. (1968) Building up a library Nursing Times 64(17) April 26562

95. Letter from Miss Thompson to J Morpurgo, 10/1/64 (RCN archive)

96. Walsh op cit. 5

97. Thompson, A. M. C. The training school library Nursing Times 56 June 3703

98. Thompson (1962a) op cit. 45

99. Book Trolley (1967) Library Association Survey 1966: First Report Book Trolley 1(11) September 3-9

100. Thompson (1962b) op cit. 1091 
101. Nursing Times (1965) Librarian for school of nursing Nursing Times 61 August 13 1095

102. Thompson (1962a) op cit. 44

103. Hospital Libraries and Handicapped Readers Group (1963) Description of Pembury meeting (16 Sept 1963) HLHRG Newsletter 5

104. Letter to National Book League 23.9.64 (RCN archive)

105. Letter to National Book League 14/12/65 (RCN archive)

106. Bunch and Cumming op cit. 8

107. ibid. 5

108. Library Association (1965) Hospital libraries: recommended standards for libraries in hospitals London. Library Association

109. ibid. 14

110. Ministry of Health (1963) Training school for nurses : Equipment note 14 London : HMSO

111. Library Association (1965) op cit. 14

112. Going, M. E. (1966) Library Services 3 - Kent Book Trolley 1(5) March 9

113. Sheffield Regional Hospital Board (1965) Working Party on Medical Libraries. Final Report Sheffield : SRHB 11

114. Williams, M. I. (1967) Report of a survey of hospital medical libraries Oxford : Oxford Regional Hospital Board

115. Sanders, B (1966) Library services in hospitals. LA pamphlet No. 27. London :

Library Association 38

116. Nursing Times (1966a) Libraries in Hospitals : Conference at The Hospital Centre

February 18230

117. Dodwell (1965) op cit. 6

118. Book Trolley (1967) op cit. 6

119. Nursing Times (1966a) op cit. 231

120. Library Association (1972) Hospital Libraries : recommended standards for libraries

in hospitals London : Library Association

121. Sturt, $R$ (1973) Review of Hospital Libraries : recommended standards for libraries in hospitals 1972 Book Trolley 3(11) September 16

122. Library Association (1978) Guidelines for library provision in the health service: a consultative document (revised 1980) London : Library Association

123. Tabor, R. B. (1969) Libraries for the Health Sciences - an interim review from

Wessex Book Trolley 2(7) September 5

124. Walsh op cit. 7

125. Committee on Nursing (1972) Report of the Committee on Nursing London: HMSO 1

126. ibid. 106

127. ibid. 109

128. Stodulski, A H \& Stafford, S M (1982) Disseminating nursing research information in the UK: nursing research abstracts from the index of nursing research. International Journal of Nursing Studies 19(4) 231-236.

129. Committee on Nursing op cit. 106

130. Pattinson, M (1975) Library and Information Services to the Cheshire Area Health authority Cheshire County libraries and Cheshire Area Health Authority 44

131. Partington, W (1975) Queen Elizabeth II Hospital library Health Welfare Libraries Quarterly 2(1) March 8

132. Knight, S (1975) Tapes and tea cups : some recent developments in the Lister Hospital Library Service Health Welfare Libraries Quarterly 2(2,3,4) June, Sept, Dec 32-35 
133. Gillespie, S (1982) Development of Libraries in Scottish Colleges of Nursing and Midwifery Eastern District College of Nursing and Midwifery 3

134. Barnes Library (1972) The development of a Regional Medical Library Service. West Midlands : proposals for development Birmingham : University of Birmingham Barnes Library 16

135. Tabor, R, ed (1978) Libraries for Health : the Wessex experience Southampton : Wessex Regional Library and Information Service 26

136. Tabor, $\mathrm{R}$ (1976) Library services in support of nursing education in Wessex: a report to the Regional Nurse Training Committee Southampton : Wessex Regional Library and Information Services

137. Thomas, G (1978) Gwynned library and information services and the Area Health Authority. A report by the County librarian Gwynned 5

138. Jess, D (1975) Student fieldwork attachments: 1. Health libraries in Edinburgh Health Welfare Libraries Quarterly 2(2-4) June - Dec 45

139. Pattinson op cit. 48

140. Thomson, M (1984) Letter to C. M. Baxter (Scottish Home and Health Department) 20 November 1984

141. General Nursing Council for England and Wales (1980) Library services (Ref 80/12) London: GNC 1

142. ibid. 2

143. Bond, S (1980) Sources and resources Nursing Times June 19, 1106-1109

144. Chakrabarty, E (1983) 'Research in nursing : school of nursing libraries as

information resources for nurse education' IN Davis, B D (ed) Research into nurse education London : Croom Helm 172

145. Tabor (1979) ibid.

146. NHS RLG (1987) Census of staff providing library services to NHS personnel Guildford : NHS Regional Librarians group 7

147. Wakeham, M. (2000) The Nursing Interest Subgroup : beginning the organization of nursing librarians Health Libraries Review 17(3) September, 157-163

148. Library Association (1982) Evidence to the United Kingdom Central Council for

Nursing, Midwifery and Health Visiting. Working Group 3, Consultation paper 1: Education and training - the development of nurse education London : Library Association

149. Leggate, $P$ (1983) Library and information services for the nursing profession (Royal College of Nursing, 10th May 1983) 3

150. DHSS/RLG (1984) Converting Information into Care : proposals arising from a series of workshops organised by the NHS Regional Librarians Group / DHSS Joint Working Party on Library services

151. Library Association (1987) Statement to the UKCC on Project 2000 London : Library Association

152. Henderson, Virginia . (1968) Library resources in nursing: their development and use. International Nursing Review 15(2) 165

153. Bunch and Cumming op cit. 21

154. Clarke, $R$ (1984) Continuing education : the role of the nursing library Nursing Information Sub-group Newsletter 4(1) Spring 4

155. Grant, A (1981) Letter NISG Newsletter 1(4) Winter 13

156. White, R. (1985) The effects of the NHS on the nursing profession 1948-1961

London : King's Fund 253-260

157. Dingwall, R, Rafferty, A M, Webster, C (1988) An introduction to the social history of nursing London : Routledge

158. Wakeham op cit. 161 
M. Wakeham : Nursing Libraries 24 